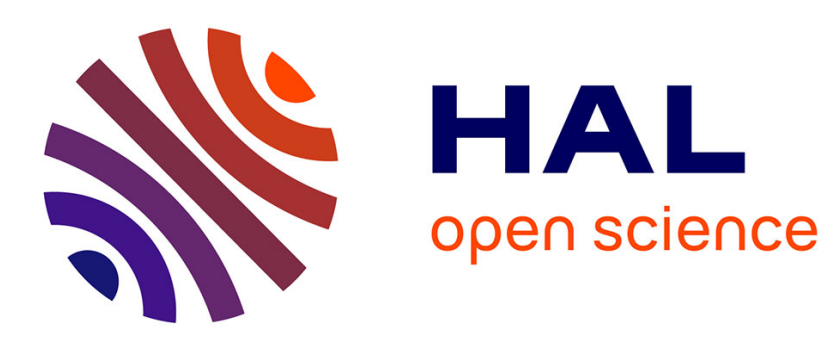

\title{
The GnRH systems in the brain and pituitary of normal and hCG treated European silver eels
}

\author{
O. Kah, S. Dufour, S. Baloche, Bernard Breton
}

\section{To cite this version:}

O. Kah, S. Dufour, S. Baloche, Bernard Breton. The GnRH systems in the brain and pituitary of normal and hCG treated European silver eels. Fish Physiology and Biochemistry, 1989, 6 (5), pp.279-284. 10.1007/BF01881681 . hal-02728188

\section{HAL Id: hal-02728188 \\ https://hal.inrae.fr/hal-02728188}

Submitted on 2 Jun 2020

HAL is a multi-disciplinary open access archive for the deposit and dissemination of scientific research documents, whether they are published or not. The documents may come from teaching and research institutions in France or abroad, or from public or private research centers.
L'archive ouverte pluridisciplinaire HAL, est destinée au dépôt et à la diffusion de documents scientifiques de niveau recherche, publiés ou non, émanant des établissements d'enseignement et de recherche français ou étrangers, des laboratoires publics ou privés. 


\title{
The GnRH systems in the brain and pituitary of normal and hCG treated European silver eels
}

\author{
O. Kah, S. Dufour', S. Baloche' and B. Breton ${ }^{2}$ \\ Laboratoire de Physiologie des Interactions Cellulaires, UA CNRS 339, Avenue des Facultés, 33405 \\ Talence Cedex, France; 'Laboratoire de Physiologie Générale el Comparée, MNHN, UA CNRS 90, 7 \\ rue Cuvier, 75005 Paris, France; 'Laboraloire de Physiologie des Poissons, INRA, Campus de \\ Beaulieu, 35042 Rennes Cedex, France
}

Keywords: GnRH immunohistochemistry, pituitary, puberty, European eel, teleost

\begin{abstract}
The distribution of immunoreactive GnRH was studied in the brain and pituitary gland of normal and human chorionic gonadotrophin (hCG) injected silver eels. It was found that the general organization of GnRH systems in this species is similar to that reported in other teleosts. Cell bodies were present in the olfactory bulbs, ventral telencephalon, periventricular hypothalamus and dorsal tegmentum. No positive perikarya could be detected in the preoptic region. Only scarce fibers were observed in the proximal neurohypophysis. Treatment with hCG does not modify the distribution of GnRH but it increases the density of positive structures, in particular at the level of the pituitary. The results are discussed in relation with the present status of knowledge of the mechanisms underlying the blockage of sexual maturation in the European eel at the silver stage.
\end{abstract}

\section{Introduction}

At the silver stage, the European eel is still an immature fish whose brain-pituitary-gonadal axis remains undeveloped until its reproductive migration to the Sargasso Sea occurs. This lack of sexual development in the silver eel results from deficient pituitary gonadotropin (GTH) synthesis and release (Dufour el al. 1983; Dufour 1985). The administration of exogenous steroids strongly enhances the synthesis but not release of GTH (Olivereau and Chambolle 1978; Dufour et al. 1983). In males, a similar effect can be obtained following stimulation of endogenous steroid production by treatment with human chorionic gonadotrophin (hCG; Dufour et al. 1983). The release of this GTH ac- cumulated in the pituitary following estrogen induction can be induced by a conjugated treatment with a mammalian gonadotrophin hormone-releasing hormone ( $\mathrm{mGrRH}$ ) and an antidopaminergic drug, pimozide (Dufour et al. 1984). This latter result is in agreement with the previous demonstration of a double neuroendocrine control of the gonadotrophic function in adult teleosts by $\mathrm{GnRH}$ and dopamine (Peter 1983). The presence of a GnRH-like factor in the eel brian and pituitary has been demonstrated by means of radioimmunoassay (Dufour et al. 1982). An increase in brain GnRH content and a strong elevation in pituitary $\mathrm{GnRH}$ content were reported following estradiol or hCG treatment, suggesting a positive effect of sexual steroids on GnRH synthesis but not release (Dufour 
et al. 1985). However, more precise data on the cerebral and pituitary distribution of $\mathrm{GnRH}$, in particular following steroids or hCG injections, were needed. The present immunocytochemical study aimed at providing neuroanatomical data on the distribution of GnRH in the brain and pituitary of control male and female eels. In addition, it was relevant to gain information about the eventual modifications in the regional distribution and subcellular localization of GnRH following hCG treatment.

\section{Material and methods}

This study was conducted on freshwater female $(250-350 \mathrm{~g} ; \mathrm{N}=10)$ or freshwater male $(70-100 \mathrm{~g})$ silver eels. The males received one injection of 250 UI hCG (Sigma) dissolved in saline solution according to Boetius and Boetius (1967; $N=9$ ) or saline alone $(N=6)$, and were sacrificed 4 months after injectjon.

For immunocytochemistry, the fish were anesthetized in MS 222 (Sandoz) and perfused via the aortic bulb with $4 \%$ paraformaldehyde in phosphate buffer (PB; $0.1 \mathrm{M} ; \mathrm{pH} 7.4)$. The brain and pituitary were removed and postfixed overnight in the same fixative at $4^{\circ} \mathrm{C}$. After washing in $\mathrm{PB}$, they were immersed in $12 \%$ sucrose for 12 hours, frozen on dry ice and cut with a cryostat. $10-15 \mu \mathrm{m}$ transverse or longitudinal sections were collected on gelatin coated slides, air dried and rehydrated in PB.

The sections were processed for the peroxidaseantiperoxidase method, the primary antibody diluted 1:2000 being either directed against mGnRH (Dubois 8631) or salmon GnRH (sGnRH; Breton et al. 1986; Kah et al. 1986). Peroxidase activity was revealed using 3-3'-diaminobenzidine $(0.0225 \%$; Sigma) and hydrogen peroxide $(0.003 \%)$.

The specificity of the antisera against sGnRH has been previously carefully examined (Breton et al. 1984,1986 ) and that of the immunohistochemical procedure was assessed by routine controls.

\section{Results}

Both antisera were tested on adjacent sections and revealed the same distribution of positive cell bodies and fibers. However, since the antiserum against sGnRH gave, at the same dilution, less background than the antibodies to $\mathrm{mGnRH}$, it was choosen for conducting this study.

\section{Control animals}

The overall pattern of distribution of immunoreactive (ir) structures, similar in both normal females and saline injected males, is represented in Fig. 1. The most anterior ir perikarya were detected within the olfactory bulbs. A few bipolar cell bodies were detected in the anterior part of the bulbs adjacent to the olfactory nerves (Fig. 1). More caudally, at the junction between the olfactory bulbs and telencephalon, a group of large perikarya was consistently found at the ventral surface of the brain (Fig. 2 ). These cells form a very well defined nucleus most likely equivalent to the nucleus olfactoretinalis (NOR) of Münz et al. (1981). At the level of the caudal portion of this nucleus, smaller bipolar or multipolar perikarya were also detected (Fig. 2).

This latter population of small cells extended along the ventral anterior telencephalon (Fig. 1) where they are located quite laterally. These ir cells were isolated or formed small clusters of 2 to 4 perikarya (Fig. 3). This population could be observed within the anterior half of the telencephalon.

More caudally no ir cells have been detected at the level of the preoptic area (POA; Fig. 5), nor in any part of the nucleus lateralis tuberis (NLT). A group of small weakly ir perikarya was noted in the dorsal posterior hypothalamus at the level of the paraventricular organ (PVO; Fremberg et al. 1977; Fig. 1).

Finally, a group of very large cell bodies was observed in the dorsal tegmentum, just caudal to the posterior commissure (Fig. 1).

ir Fibers were observed in numerous parts of the brain and in many cases, it was not possible to trace them. However, several main tracts could be distinguished.

A continuous rostro-caudally oriented bundle was observed from the anterior olfactory bulbs to the POA (Fig. 1). This bundle crossed all ventral 


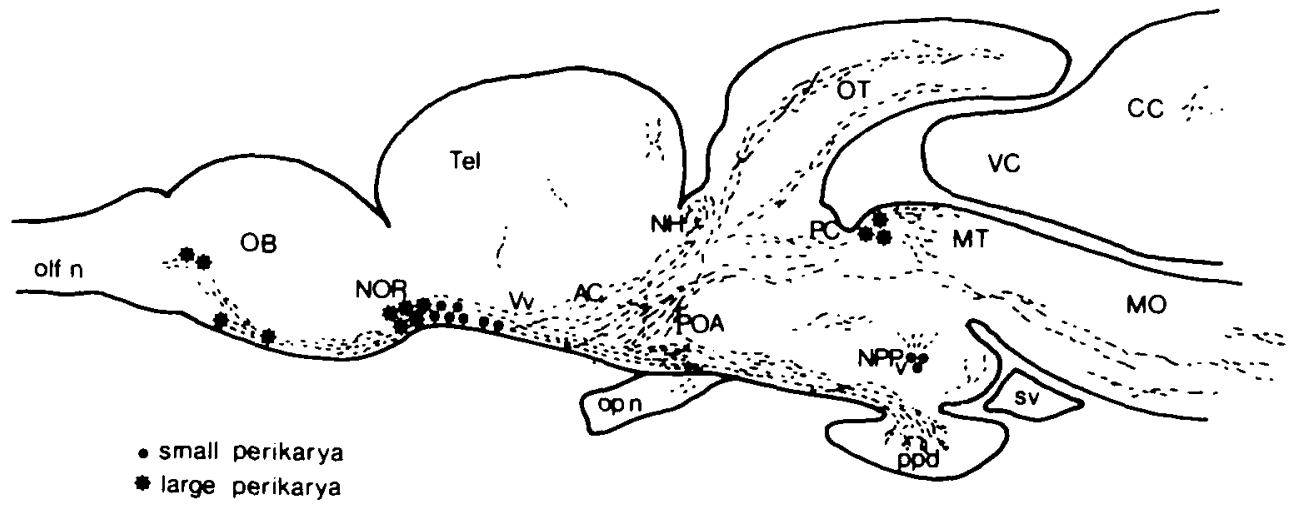

1

Fig. 1. Diagram summarizing the distribution of (inRH cell bodies and fibers (dotted lines) on a longitudinal section of the eel brain. AC: anterior commissure; CC: corpus of the cerebellum; MO: medulla oblongata; MT: midbrain tegmentum; NH: habenular nucleus; NOR: nucleus offactoretinalis; NPPv: nucleus posterioris periventricularis; $O B$ : olfactory bulb; olf $n$ : olfactory nerve; op n: optic nerve; OT: optic tectum; PC: posterior commissure; POA: preoptic area; ppd: proximal pars distalis: sv: saccus vasculosus; Tel: telencephalon; VC: valvula of the cerebellum; $V_{v}$; ventral telencephalon.

areas where ir cell bodies were described above and reached the rostral preoptic region (Fig. 5). From the POA, fibers ascended laterally along the optic tracts. Part of these fibers enter the habenular nucleus (NH; Fig. 1), while others continued more caudally to ascend in the torus longitudinalis and the optic tectum.

From the POA, another important tract reached the pituitary stalk through the lateral preoptic region and the laterobasal hypothalamus. At the level of the pituitary stalk, fibers converged to enter the digitations of the proximal neurohypophysis where scarce positive profiles were detected (Fig. 6). No ir fibers were observed in the adenohypophysis, the rostral neurohypophysis or the neurointermediate lobe.

In addition to these main tracts, ir profiles were found in other brain territories such as the dorsal parts of the olfactory bulbs and telencephalon, the optic nerve, the tegmentum and the medulla oblongata (Fig. 1).

\section{HCG treated males}

In hCG treated males, the qualitative distribution of ir fibers and cell bodies was similar to that observed in control males and females. The most striking difference was the dramatic increase in the number and intensity of ir endings at the level of the proximal neurohypophysis of hCG treated males compared to control animals (Fig. 7, compare with Fig. 6). Although it is difficult to objectively appreciate visually, it appeared that the density and number of ir structures in the anterior brain, in particular the ventral telencephalon (Fig. 4) was higher in hCG treated males than in controls, but this increase was not as evident as in the pituitary.

\section{Discussion}

The present immunohistochemical investigation confirms that a GnRH-like factor is present and widely distributed in the eel brain at the silver stage. This is in agreement with a previous report based on radioimmunoassays (Dufour et al. 1982). In addition, it provides more detailed information concerning the distribution of this factor within the brain and pituitary.

The general organization of the GnRH systems in the European eel is in accordance with that reported so far in teleosts (for review see Kah 1986) and in particular in the Japanese eel (Nozaki 1985). Indeed, the large ir cell bodies observed in the NOR have been described already in a number of species, 


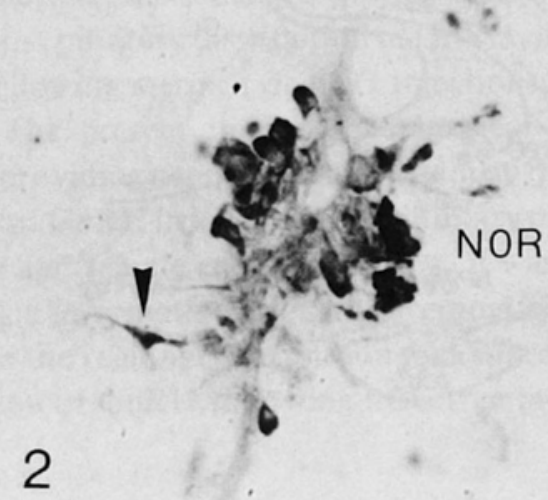

4

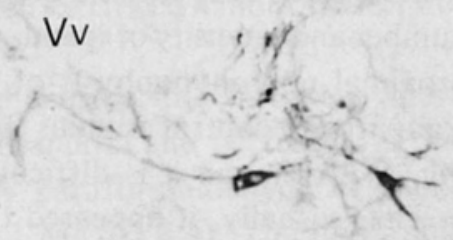

r i

$\mathrm{ppd}$

\section{6}

Figs. 2-7. Transverse cryostat sections of silver eel brain processed for immunocytochemistry with an antiserum against salmon GnRH. Fig. 2. The ir cell bodies of the nucleus olfactoretinalis (NOR) located at the junction of the olfactory bulbs and telencephalon. While the cells of the NOR are large and globular, smaller ir perikarya (arrow) are frequently located in their vicinity ( $\times 180)$.

Figs. 3 and 4 . In both control (Fig. 3) and hCG treated males (Fig. 4), ir cell bodies were detected in the ventral telencephalon (Vv), without significant differences in their number and intensity $(\times 180)$.

Fig. 5. No ir cells bodies could be observed at the level of the preoptic area, but numerous ir fibers (arrows) were present lateral to the nucleus preopticus periventricularis (npp) and in the ventral wall of the preoptic recess (rpo). npo: nucleus preopticus ( $X$ 180).

Figs. 6 and 7. Transverse sections at the level of the proximal pars distalis (ppd) of a control male (Fig. 6) and an hCG-injected male (Fig. 7). Note the striking difference in the number of ir terminals observed in the digitations (arrows) of the neurohypophysis. ri: infundibular recess $(\times 67)$. 
such as the platyfish (Münz et al. 1981; HalpernSebold and Schreibman 1983) and the sole (Nunez Rodriguez et al. 1985). This nucleus according to recent data is a component of the terminal nerve, a cranial nerve having connections with both olfactory and visual systems, and involved in the integration of environmental cues (Demski and Northcutt 1984; Stell et al. 1984; Kah et al. 1986). In mammals, the terminal nerve is composed of several $\mathrm{mGnRH}$ containing ganglia located at the ventral surface of the anterior brain (Shwanzel-Fukuda and Silverman 1980). In the European eel, there is a possibility that the different populations of ir cell bodies observed in the olfactory bulbs as suggested in the Japanese species by Nozaki (1985), and even that of the anterior ventral telencephalon all belong to the terminal nerve. This latter population, according to its situation and the size and shape of its neurons, appears similar to that previously described by Kah et al. (1986) in the goldfish.

The presence of ir perikarya in the periventricular diencephalic area has already been reported by Borg et al. (1982) in the stickleback. However, according to these authors, such positive cells were found in a large region extending from the dorsal hypothalamus to the dorsal thalamus. In the present study, ir neurons were detected only in an area described as being part of the monoamine containing paraventricular organ (Fremberg et al. 1977). Most likely, this area corresponds to the goldfish nucleus posterioris periventricularis of Peter and Gill (1975), which was reported to concentrate sexual steroids (Kim et al. 1978).

Large ir perikarya similar to those observed in the eel have already been described in the anterior dorsal tegmentum of the platyfish (Münz et al. 1981), the stickleback (Borg et al. 1982) and the gold fish (Kah et al. 1986). However, their functional significance remains unknown.

In addition to these similarities concerning the distribution of cell bodies, a high level of homology also occurs in the organization of their main projections (Münz et al. 1981; Nozaki 1985; Schreibman et al. 1984; Kah et al. 1986).

Nevertheless, in contrast with most previous studies (see review by Kah et al. 1986), no positive cell bodies could be observed in the ventral POA which, however, contains numerous ir fibers. This fact could be related to the immature status of the eel at the silver stage. Indeed, Halpern-Sebold and Schreibman (1983) in the platyfish have suggested that during the ontogeny of the GnRH systems, the ir perikarya appear first at the level of the NOR, and then, at the onset of puberty, in the POA. In addition, several lines of evidence suggest that the preoptic region is mainly involved in the final steps of sexual maturation (Kah 1986).

In hCG treated males, the slight elevation in the brain immunoreactivity is consistent with the low increase in brain radioimmunoassayable content (Dufour et al. 1985). The effect of hCG on GnRH levels and on gonadotrophin level is probably mediated by the elevation of the production of endogenous androgens (see Dufour 1985), although a direct effect of hCG itself cannot be, at present, totally ruled out. A positive action of sexual steroids on brain $\mathrm{GnRH}$ was suggested in platyfish by Schreibman et al. (1986) and in trout by Goos et al. (1986). A stimulation of GnRH synthesis by sexual steroids is also well documented in mammals (review in Kalra 1985).

It must be pointed out that, in hCG treated eels, only the GnRH structures already existing in controls could be detected and that perikarya did not appear in other brain regions, in particular the POA. In the pituitary, the strong increase in the number and density of nerve endings in hCG treated animals is in good agreement with the finding of a large elevation (up to 10 times) in the radioim-

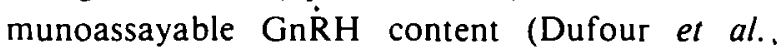
1985). In addition, the present immunohistochemical study demonstrates that GnRH is accumulated in the axonal endings of the proximal neurohypophysis. In particular, GnRH does not appear to be internalized in adenohypophyseal cells as observed by Margolis-Kazan et al. (1981) in the platyfish. These data strongly suggest a lack of GnRH release in the eel pituitary, which could play, beside the dopaminergic inhibition (Dufour et al. 1984), an important role in the blockage of the gonadotrophic function and gonadal development at the silver stage. 


\section{References cited}

Borg, B., Goos, H.J.Th. and Terlou, M. 1982. LHRHimmunoreactive cells in the brain of the three spined stickleback, Gasterosteus aculeatus L. (Gasterosteidae). Cell Tiss. Res. 226: 695-699.

Breton, B., Motin, A, Kah, O., Le Menn, F., Geoffre, S., Précigoux, G. and Chambolle, P. 1984. Dosage radioimmunologique homologue d'un facteur hypothalamique de stimulation de la fonction gonadotrope hypophysaire de Saumon sGnRH. C.R. Acad. Sci., Paris, Ser. III, 299: 383-388.

Breton, B., Motin, A., Billard, R., Kah, O., Geoffre, S. and Précigoux, G. 1986. Immunoreactive gonadotropin-releasing hormone-like material in the brain and the pituitary gland during the periovulatory period in the brown trout (Salmo trutta L.): relationships with the plasma and pituitary gonadotropin. Gen. Comp. Endocrinol. 61:109-119.

Demsky, L.S. and Northcutt, R.G. 1984. The terminal nerve: a new chemosensory system in the vertebrates. Science 202 : 435-437.

Dufour, S. 1985. La fonction gonadotrope de l'Anguille européenne. Anguilla anguilla L., au stade argentée (au moment du départ pour la migration de reproduction): les mécanismes de son blocage et sa stimulation expérimentale. Thèse Dr. Sci. Múséum National d'Histoire Naturelle. Université de Paris VI.

Dufour, S., Pasqualini, C., Kerdelhué, B. and Fontaine, Y.A. 1982. Presence and distribution of radioimmunoassayable LHRH in the European eel, Anguilla anguilla. Neuropeptide 3: $159-171$.

Dufour, S., Delerue-Le Belle, N. and Fontaine, Y.A. 1983. Effects of steroid hormones on pituitary immunoreactive gonadotropin in European freshwater eel, Anguilla anguilla L. Gen. Comp. Endocrinol. 52: 190-197.

Dufour, S., Delerue-Le Belle, N. and Fontaine, Y.A. 1984. Stimulation de la libération d'hormone gonadotrope et du développement des gonades sous l'effet conjugué du pimozide et d'un antagoniste de la LHRH chez l'Anguille femelle argentée prétraitée à l'oestradiol. C.R. Acad. Sci., Paris, Série 111, 299: 231-234.

Dufour, S., Fontaine, Y.A. and Kerdelhué, B. 1985. Increase in brain and pituitary gonadotropin releasing hormone $(\mathrm{GnRH})$ in the European silver eel treated with sexual steroid or human chorionic gonadotropin. Neuropeptides 6: 495-502.

Fremberg, M., Van Veen, Th. and Hartwig, H.G. 1977. Formaldehyde induced fluorescence in the telencephalon and diencephalon of the eel (Anguilla anguilla L.). A fluorescence-microscopic and microspectrofluorimetric investigation with special reference to the innervation of the pituitary. Cell Tiss. Res. 176: 1-22.

Goos, H.J.Th., De Leeuw, R., Cook, H. and Van Oordt, P.G.W.J. 1986. Gonadotropic hormone-releasing hormone ( $\mathrm{GnRH}$ ) bioactivity in the brain of the immature rainbow trout, Salmo gairdneri. The effect of testosterone. Gen. Comp. Endocrinol. 64: 80-84.

Halpern-Sebold, L.R. and Schreibman, M.P. 1983. Ontogeny of centers containing luteinizing hormone-releasing hormone in the brain of platyfish (Xiphophorus maculatus) as deter- mined by immunocytochemistry. Cell Tiss. Res. 229: 75-84.

Kah, O. 1986. Central regulation of reproduction in teleosts. Fish Physiol. Biochem. 2: 25-34.

Kah, O., Breton, B., Dulka, J.G., Nunez Rodriguez, J., Peter, R.E., Corrigan, A., Rivier, J.E. and Vale, W.W. 1986. A reinvestigation of the $\mathrm{Gn}-\mathrm{RH}$ (gonadotrophin-releasing hormone) systems in the goldfish brain using antibodies 10 salmon Gn-RH. Cell Tiss. Res. 244: 327-337.

Kalra, P.S. 1985. Stimulation of hypothalamic LHRH levels and release by gonadal steroids. J. Ster. Biochem. 23: $725-731$.

Kim, Y.S., Stumpf, W.E. and Sar, M. 1978. Topography of estrogen target cells in the forebrain of the goldfish, Carassius auratus. J. Comp. Neurol. 182: 611-620.

Leloup-Hatey, J., Khan, I.A., Lopez, E., Dufour, S. and Fontaine, Y.A. 1984. Stimulation testiculaire chez l'anguille européenne: comparaison des effets de l'hCG et de la cGTH. Réun. Physiol. Poissons, Paimpont.

Margolis-Kazan, H., Peute, J., Schreibman, M.P. and Halpern, L. 1981. Ultrastructural localization of gonadotropin and luteinizing hormone-releasing hormone in the pituitary gland of a teleost (the platyfish). J. Exp. Zool. 215: 99-102.

Münz, H., Stumpf, W.E. and Jennes, L. 1981. LH-RH systems in the brain of platyfish. Brain Res. 221: 1-13.

Nozaki, M. 1985. Tissue distribution of hormonal peptide in primitive fishes. In Evolutionary Biology of Primitive Fishes. pp. 433-454. Edited by R.E. Foreman, A. Gorbman, J.M. Dodd and P. Olsonn. Plenum Press, New York.

Nunez Rodriguez, J., Kah, O., Breton, B. and Le Menn, F. 1985. Immunocytochemical localization of GnRH (gonadotropin releasing hormone) systems in the brain of a marine teleost fish, the sole. Experientia 41: 1574-1576.

Olivereau, M. and Chambolle, P. 1978. Ultrastructure des cellules gonadotropes de l'Anguille normale et après injection d'oestradiol C.R. Acad. Sci. Paris, Sér.D, 287: 1409-1412.

Peter, R.E. and Gill, V.E. 1975. A stereotaxic atlas and technique for forebrain nuclei of the goldfish, Carassius auratus. J. Comp. Neurol. 159: 69-102.

Schreibman, M.P., Margolis-Kazan, H., Halpern-Sebold, L., O'Neill, P.A. and Silverman, R.C. 1984. Structural and functional links between olfactory and reproductive systems: puberty-related changes in olfactory epithelium. Brain Res. 302: $180-183$.

Schreibman, M.P., Margolis-Nunno, H., Halpern-Sebold, L., Goos, H.J.Th. and Perlman, P.W. 1986. The influence of androgen administration on the structure and function of the brain-pituitary-gonad axis of sexually immature platyfish, Xiphophorus maculatus. Cell Tiss. Res. 245: 519-524.

Schwanzel-Fukuda, M. and Silverman, A.J. 1980. The nervus terminalis of the guinea pig: a new luteinizing hormonereleasing hormone (LHRH) neuronal system. J. Comp. Neurol. 191: 213-225.

Stell, W.K., Walker, S.E. Chohan, K.S. and Ball, A.K. 1984. The goldfish nervus terminalis: a luteinizing hormonereleasing hormone and molluscan cardioexcitatory peptide immunoreactive olfactoretinal pathway. Proc. Nat. Acad. Sci. U.S.A. 81 : $940-944$ 